Jakub Żmidziński

Wydział Edukacji Artystycznej i Kuratorstwa,

Uniwersytet Artystyczny Poznaniu

\title{
„Wędrowiec-dantofil” w rodzinnej Italii. \\ Stanisław Vincenz a włoska tradycja artystyczna
}

Urodził się i wychował u podnóża Karpat Wschodnich', kiedy Europa Środkowa była jeszcze niemal dziewiczą krainą współistnienia wielu sąsiadujących ze sobą narodów. Już w dzieciństwie posługiwał się kilkoma językami, a w trakcie dalszej edukacji oraz indywidualnych poszukiwań i badań poznał ich blisko piętnaście. Zakres tych badań był rzeczywiście imponujący. Stanisław Vincenz ukończył gimnazjum w Kołomyi (przez pewien czas uczył się też w Stryju), a następnie studia w Wiedniu. Obronił doktorat z filozofii, lecz po utracie napisanej rozprawy habilitacyjnej² porzucił ostatecznie myśl o poświęceniu się tej dziedzinie nauki. Gdy ucichła zawierucha wojenna, porzucił stanowisko naczelnika Wydziału Narodowościowego w Ministerstwie Spraw Wewnętrznych i pracę w redakcji piłsudczykowskiej „Drogi”. Zamieszkał w sercu Czarnohory i rozpoczął nowy, znaczony literaturą, etap swego życia. Etap wypełniony pisaniem nie tylko eposu Na wysokiej potoninie, lecz także licznych

1 Stanisław Vincenz urodził się w Słobodzie Rungurskiej w 1888 roku; zmarł w Lozannie w 1971 roku.

2 Rozprawa habilitacyjna spłonęła wraz z dworem w Krzyworówni w czasie I wojny światowej. 
esejów, w znacznej części dotyczących antycznej i europejskiej tradycji literackiej, a w szczególności dzieła Dantego Alighieri.

Spośród trzech swoich mistrzów: Homera, Platona i Dantego, to właśnie temu ostatniemu Vincenz poświęcił najwięcej uwagi. W tym związku zachodziła bowiem wewnętrzna symbioza: wymiana doświadczeń między badaczem a pisarzem. Boska Komedia miała ogromny wpływ na ukształtowanie Vincenza jako myśliciela i twórcy, ale oddziaływała też bezpośrednio na niektóre aspekty jego tetralogii. Dla artysty istotna była również znajomość tradycji i sztuki włoskiej, a nade wszystko liczne włoskie podróże. Dzięki takim podstawom pisarz mógł formułować oryginalne refleksje na temat włoskiego pejzażu, włoskiej kultury i jej podobieństw z kulturą polską. Wpłynęły one także na jego wizję Europy. Warto przyjrzeć się najpierw włoskim epizodom w biografii Vincenza, by następnie wyłuskać z jego twórczości motywy związane z tradycją Italii. Może rzuci to nowe światło na omawiane dzieło literackie oraz ukaże oryginalną perspektywę spojrzenia pisarza na obszar Półwyspu Apenińskiego. Pisano już o związkach Vincenza z Huculszczyzną, o Tematach żydowskich i węgierskich śladach pisarza, wątkach ormiańskich i austriackich, o „Grecji Vincenza”, a nawet o „Innej Rosji” wyłaniającej się z jego pism - teraz przyszedł czas na Italię [por. np. Woldan 1992: 127-133; Snopek 1994: 5-18; Madyda 2002: 163-170; Pálfalvi 2002: 61-69; Grajewski 2003: 133-142; Sucharski 2008: 159-184; Burda-Fischer 2015; Zięba 2015: 375-420].

\section{Włoskie peregrynacje: Wenecja - Neapol - Toskania}

Z biografii Sokratesa Karpat opracowanej przez Mirosławę Ołdakowską-Kuflową wynika, że w okresie powojennym Irena i Stanisław Vincenzowie, po osiedleniu się we francuskim Grenoble, a później szwajcarskiej Lozannie, odwiedzili Włochy parokrotnie. Kilka z tych podróży szczegółowo opisała Irena w Rozmowach ze Stanisławem Vincenzem. Jednak biografka wspomina również o wcześniejszych peregrynacjach pisarza na Półwysep Apeniński. Niestety wiemy o nich bardzo mało. Pisarz zaledwie napomkną o swojej pierwszej wizycie we Włoszech w eseju $Z$ perspektywy podróży: 
Już wspomnienie mojej pierwszej podróży do Włoch północnych w roku 1907, tak improwizowanej i po prostu „na wariata”, jak się mówiło po lwowsku, budzi we mnie złudzenie, że jestem tu i tam równocześnie. [Vincenz 1980: 13]

Ten krótki pobyt pozwolił mu snuć porównania architektury włoskiej z lwowską.

O drugim swoim zetknięciu z włoską ziemią Vincenz nigdy bodaj nie wspomniał w jakichkolwiek zapiskach. Miało to miejsce w roku 1915, kiedy odbywał służbę wojskową w 24 pułku piechoty, gdzie w czwartym batalionie, „zanim został adiutantem, dowodził plutonem” [B: 83]. Jak dalej relacjonuje autorka biografii: „[...] zachowała się $[\ldots] \mathrm{w}$ rodzinie pamięć o udziale pisarza w wojnie na froncie włosko-austriackim w 1915 r." [B: 83]. Najprawdopodobniej Vincenz brał wtedy udział w niezwykle zaciętych i krwawych walkach frontowych przebiegających na linii Dolomitów; w trakcie tych potyczek zginął jego żydowski przyjaciel Max Gruber, protoplasta powieściowego Piotrusia Sawickiego.

W eseju Polityk niepolityczny Vincenz wspomina kolejny swój przedwojenny pobyt w Wenecji, odnosząc się - jak zauważyła autorka biografii - do owego pierwszego, wspomnianego już pobytu:

Właśnie z profesorem Bartlem nasz stosunek umocnił się przez pośrednictwo Włoch północnych. Już jako dobrzy znajomi spotkaliśmy się, po jego rezygnacji ze stanowiska premiera w roku 1928, w Wenecji. [... ] Miałem wówczas rzadką sposobność popisywać się znajomością Wenecji, datującą się sprzed dwudziestu lat, kiedy oczekując na pieniądze z domu, wypełniałem nadmiar czasu przechadzkami po zawikłanych uliczkach i nad laguny, i to dniem i nocą. [...] Lecz i ów człowiek nowoczesny [Bartel - J.Ż.], mimo rzekomo prostolinijną fantazję zgadzał się ze mną w krytyce przewodnika po Włoszech pióra historyka Burckhardta. Ten bowiem nie doceniał czaru kościoła Św. Marka, uważając go niesłusznie za nieograniczoną mieszaninę stylów. A dla nas, mieszkańców wschodu, takie mieszaniny nie były niczym niezwykłym i wcale nas nie razily. [Vincenz 1983b: 102-103] 
Już w tym fragmencie pisarz daje świadectwo swego zainteresowania sztuką i architekturą tego regionu, co potwierdza w dalszych wywodach dotyczących pałacu Dożów i innych zabytków. Całość podsumowuje słowami:

[...] nasze wędrówki po galeriach, kościołach, budynkach i placach weneckich należą do mych najmilszych wspomnień z tej dziedziny obok niezapomnianych wystaw Rembrandta i El Greca, zebranych z całego świata, jakie widziałem nieco później w Niemczech. [B: 103]

Trudno powiedzieć, kiedy Vincenz zainteresował się sztuką włoską (świadczy o tym jego uczestnictwo na wykładach prof. Schlossera [B: 63]). Czy owa pasja była pokłosiem tego młodzieńczego wyjazdu, czy może może iskrą rozpalającą fascynację tradycją kulturową Italii było młodzieńcze zamiłowanie do twórczości autora Boskiej Komedii? Esej zatytułowany Dante a mity ludowe Vincenz wieńczy obszernym passusem wspomnieniowym, w którym przytacza swoje wystąpienie na kółku literackim w gimnazjum w Stryju, do którego uczęszczał w latach 1904-1905. Jako szesnastolatek porównał wtedy podanie pochodzące z gór Synyci z poematem Dantego [Vincenz 1997: 261-262] i - jak sam dodaje - już wtedy, „bez przymusu szkolnego czy egzaminacyjnego” [B: 262] wybrał sobie za przewodnika poetę z Florencji. Ta fascynacja nie opuściła go nawet w najtrudniejszym okresie. Świadczy o tym wojenny notatnik Outopos, w którym wielokrotnie przytacza fragmenty z dzieła Dantego [zob. Vincenz 1993]. Jednym z jego pisarskich niespełnień jest ostateczne porzucenie idei wydania obszernej książki poświęconej Alighieriemu, choć pokaźna liczba dziewięciu esejów mających w sumie ponad sto pięćdziesiąt stron jest sporym wkładem w polską dantologięs. Tu jednak skoncentrujemy się głównie na motywach włoskich obecnych w utworze $\mathrm{Na}$ wysokiej połoninie (dalej: Połonina). Nim do nich przejdziemy, musimy do końca zreferować włoskie peregrynacje Vincenza. 
Choć w okresie powojennym, już jako emigrant, marzył Vincenz o licznych podróżach, niewiele z nich udało mu się urzeczywistnić. Bywał w Niemczech, gdzie mieszkał jego syn Andrzej, i w Anglii, gdzie osiadła jego pierwsza żona, Lena. Miał również to szczęście, że jeden z jego przyjaciół, szwajcarski panidealista ${ }^{4}$, badacz literatury i pedagog John Marbach, przez szereg lat był dyrektorem Scuola Svizzera w Neapolu. Z jego gościny miał okazję kilkakrotnie skorzystać.

Pierwsza włoska podróż Vincenza jako emigranta rozpoczęła się późną wiosną 1955 roku, głównie dzięki zaproszeniu przyjaciela. W swoich zapiskach Irena wspomina o niej marginalnie: „St. wrócił z Italii odmieniony. Właściwie już się odmienił trochę przed wyjazdem, od chwili, kiedy wiedział już, że pojedzie" (4 czerwca 1955) [R 1993, nr 3: 111]. Następnie autorka przytacza krótką relację męża: „Bardzo było wszystko dobrze, wszędzie dobre wino, jedno tylko tu lepsze, to łóżka, a w Rzymie w klasztorze takie wąskie, że bałem się, że się przewrócę” (4 czerwca 1955) [R 1993, nr 3: 111-112]. Redaktor Rozmów... , syn pisarza Andrzej, dodał jeszcze w przypisie taką wiadomość: „Podróż do Rzymu, dokąd pisarza zaprosił abp Buczko, i do Neapolu, gdzie był gościem Johna Marbacha” (4 czerwca 1955) [R 1993, nr 3: 111]. Już po śmierci Vincenza, w 1976 roku, w londyńskich „Wiadomościach” ukazał się artykuł Johna Marbacha relacjonujący rozmowę, jaką wtedy odbył ze swoim przyjacielem. Dyskusja, która dotyczyła głównie kwestii rozwoju i historii widzianej z perspektywy historiozoficznej, odbyła się w Neapolu. Ów szwajcarski germanista plastycznie oddał lokalny koloryt i nastrój chwili, co rzuca światło na charakter włoskich przeżyć karpackiego Sokratesa:

Siedzieliśmy na obszernym tarasie starego pensjonatu, oddaleni o rzut kamienia od pałacu Benedetta Croce na via Crispi. Przed nami najwspanialszy widok świata: granatowa zatoka neapolitańska, na lewo delikatnie wznoszące się ku lazurowemu sklepieniu nieba kontury Wezuwiusza, który właśnie świecił 
w białym kręgu świeżego śniegu; na prawo, między murami koloru ochry, ciemne sady pomarańczowe z błyszczącymi owocami, przed nami szerokie morze. [Marbach 1976: 2]

W późniejszym czasie Vincenzowie dwukrotnie skorzystali jeszcze z zaproszenia do Neapolu. Przebieg obu tych wizyt relacjonuje w swoich zapiskach żona pisarza. Pierwsza podróż odbyła się jesienią 1958 roku. Pobyt we Włoszech trwał od 9 października do 7 listopada. Stan fizyczny siedemdziesięcioletniego wówczas Vincenza nie był już najlepszy. Szczególnej rehabilitacji wymagała jego noga, toteż ważnym elementem pobytu były starania o podratowanie zdrowia pisarza. Irena dokładnie relacjonuje podróż pociągiem, przesiadki i przygodne rozmowy ze współpasażerami, pobyt u Marbacha, spotkania i toczone dysputy, wyjazdy (m.in. do Fossa Nuova) i mijane pejzaże, gdzieniegdzie wtrącając uwagi na temat mieszkańców Włoch: „Ludzie, jak u nas we Lwowie - spytasz jednego o drogę, a już cię pięciu prowadzi i uśmiechają się, mają czas dla ciebie" (2o października 1958) [R 1994, nr 4: 131]. Na wyspie Ischia, w miejscowości Forio Vincenzowie spędzili ponad tydzień, odpoczywając i biorąc lecznicze kąpiele.

Druga podróż miała miejsce w roku 1960. Pobyt we Włoszech trwał od 17 maja do 29 czerwca. Pierwszych osiem dni Vincenzowie spędzili nad morzem w miejscowości Rapallo. Wtedy też Stanisław dwukrotnie odwiedził w Nervi poważnie schorowanego Aleksandra Wata. Podobnie jak wcześniej następnie udali się do Neapolu, gdzie zatrzymali się u Marbacha, a stamtąd znów podążyli do Forio na wyspie Ischia. W notatkach żony powraca wtedy często problem braku pieniędzy, który nękał pisarza właściwie przez cały okres życia emigracyjnego. Doskwierała mu także pogłębiająca się niesprawność nogi. Mimo to Vincenz starł się głębiej spoglądać na otaczający pejzaż i odnajdywać w nim ślady dawności - jak zapisała słowa Stanisława jego żona:

Nie masz pojęcia, jak mnie pasjonuje myśl, że to na tej wyspie był Odys, lubię sobie to wyobrażać. Te ciepłe źródła w San Angelo, czy to nie tam szła ze służebnymi Nausikaa prać bie- 
liznę? Lubię sobie to wyobrażać, jakby to była moja rodzina. (6 czerwca 1960) [R 1995, nr 2: 41]

Ta, zdawałoby się, banalnie brzmiąca uwaga, odsłania jednak ważny aspekt myślenia i twórczości Vincenza, do czego przyjdzie nam jeszcze powrócić. I tutaj czytamy uwagi Ireny o mieszkańcach Włoch, ich uczciwości i biedzie panującej wówczas w tym kraju. Zarówno w Forio, jak i później w Neapolu Stanisław miał okazję spotkać się z gronem znajomych, swoich i Marbacha, do których należeli: prof. Reinhard Dohrn i jego córka, Gustaw Herling-Grudziński, poetka Anna Banet i jej mąż, malarz Rudolf Banet.

Vincenz odbył również dwie podróże do północnych Włoch. Pierwszą była trwająca od 16 do 23 sierpnia 1959 roku wycieczka samochodowa, w jaką pisarz wyruszył z rodziną Stanisława, syna z pierwszego małżeństwa. Wspólnie zwiedzili wtedy Turyn, Parmę, Mediolan, Bolonię, a w końcu zatrzymali się w Urbino w Marchii [por. R 1959, 1995, nr 1: 106-107]. Pod wpływem tych doświadczeń powstał esej $Z$ perspektywy podróży. Tekst rozpoczyna się od postawienia postulatu, by szukać „ukrytych związków” w krajobrazie:

Można znaleźć więcej niż jedno uzasadnienie, aby podróżując lub zatrzymując się w północnych Włoszech od Rawenny po Bolonię i dalej ku Urbino, Loreto i Ankonie, wspominać odległą Polskę i kraje tak czy inaczej dziejowo z nią związane. [Vincenz 1980: 13]

W tym kontekście zwraca pisarz uwagę na „wylew architektury włoskiej na wschód Europy" [Vincenz 1980: 13], wspomina znanych Polaków związanych z mijanymi miejscami, w końcu wskazuje na „podobieństwo między ludźmi”: przywołując Marchię, pisarz przypomina Lwów, a także akcentuje wspólne, Włochów i Polaków, doświadczenie emigracji. Kluczem do snucia tych analogii wydaje się kwestia wspólnoty, do której pisarz co jakiś czas powraca. Te porównania autor wieńczy konkluzją: „[... ] zwłaszcza zewnętrzne Włochy nieraz przypominają Polskę, pełno kościołów, tylko trochę mniej księży po parafiach niż w Polsce, a równocze- 
śnie merowie i municypia komunistyczne jak właśnie w Urbino”s [Vincenz 1980: 16]. Ten niedługi esej, wprowadzający w pejzaż północnych Włoch, pisarz kończy uwagami o wielości i dobrej jakości tutejszych dróg, zarazem o wrażeniu braku dynamiki w kraju nad Adriatykiem. Konstatacje na ten temat są mu potrzebne, by snuć refleksję o przyszłości, w której dzięki „przewalcowaniu” przez historię znikną „może różnice między ludźmi, między regionami, między prowincjami i wreszcie między narodami”, co sprawi, że ludzie uznają, iż „wojna to nonsens”. Ale jakby sam nie dowierzał swoim słowom, pisze dalej:

Czy w krajobrazie starym, zanurzonym w mgliste dzieje „cyklopów”, fenickie czy homeryckie, a dziś przewalcowanym i oczekującym nowych warsztatów aż życie stanie się znośne, wykwitną kiedyś nowe różnice nie groźne, nie drapieżne, lecz twórcze? [Vincenz 1980: 18]

Charakterystyczne dla Vincenza jest to poszukiwanie w krajobrazie śladów dawności, pracy dziejów - najgłębszych ich pokładów. Wspólnota bowiem, do której się - za Dantem - odwoływał, dotyczyła nie tylko ludzi żywych, lecz także relacji z tymi, którzy odeszli, i tymi, który przyjdą.

Ostatni, a zarazem najdłuższy pobyt Vincenza we Włoszech miał miejsce w latach 1961-1962. Jego charakter był nieco inny, związany z planami pisarskimi, jak to relacjonował Stanisław w liście do Rostysława Jendyka ${ }^{6} \mathrm{z} 17$ września 1961 roku:

W przyszłym tygodniu wyjeżdżamy do Florencji, bo ja nareszcie uprzytomniłem sobie, iż kończę lat 73, czyli że trzeba sfinalizować zbyt długie studia uprawiane jeszcze w Słobodzie Rungurskiej nad Dantem i napisać ostatecznie dzieło Obecność Dantego, które będzie wynosić co najmniej 500 stron. (17 września 1961) [R 1996, nr 1: 113] 
Vincenzowie na dłużej zatrzymali się w miejscowości Ulivello pod Florencją. W liście do Maryli i Wita Tarnawskich, datowanym na 16 listopada 1961 roku, Stanisław donosi:

W miarę możności szwendamy się trochę do Florencji i po Florencji, chociaż moja noga coraz większe sprawia mi trudności, a także po prostu powoduje zmęczenie. Jednak fortele Dantejskie furczą mi po głowie i ciągle coś zapisuję jako szczegóły i wersje dla ilustracji horyzontu, który wydaje mi się niezmiernie ważny. Ostatnio podnieca mnie studium podłoża, tj. Etrurii starożytnej wraz z jej nieustannymi Dziadami i kontaktem ze zmarlymi. Bo to, zdaje się, nie wiem jakim sposobem, odziedziczył Dante. (16 listopada 1961) [R 1996, nr 1: 115]

Pokłosiem tego wyjazdu są refleksje o etruskich korzeniach idei Dantego, obecne w kilku esejach: Arcydzieło a mit ludowy, Tto Dantego, Siedemsetna rocznica urodzin Dantego i przede wszystkim Dante a mity ludowe (w tym tekście kwestię podglebia etruskiego w Toskanii i jego wpływu na Boska Komedię pisarz rozwija najbardziej). Aby znaleźć dowody na potwierdzenie tezy o etruskim charakterze fonetyki toskańskiej, Vincenz wciela się w podróżnika-etnografa, czyli w rolę, która była podstawą jego warsztatu pisarskiego na Huculszczyźnie: „Gdy wędrowiec-dantofil wędruje po Toskanie i porozumiewa się z tamtejszym życzliwym ludem, zauważa wkrótce szczególnie przydechowe, nieco chrapliwe dźwięki tamtejszej wymowy" [Vincenz 1997: 244-245]. Swoje spostrzeżenia wieńczy, jak niemal zawsze, refleksją o charakterze uniwersalnym: „Dźwięk dialektu toskańskiego budzi nas i prowadzi przez podziemne chodniki jakiejś niesamowitej dziedziczności bardzo, bardzo daleko” [Vincenz 1997: 245]. Jednak nie tylko w języku szukał Vincenz owych powinowactw, lecz także w obrzędowości ludowej związanej ze zmarłymi oraz w sztuce. W swoich przypuszczeniach szedł równolegle ze współczesną mu dantologią; powoływał się nieraz na znanych badaczy ${ }^{7}$, choć niektóre jego pomysły mają charak-

7 Pisarz wymienia m.in.: Karla Vosslera, Asin Palaciosa, Theophila Spörri i Konstantego Michalskiego. 
ter oryginalny: „Można natomiast zaproponować coś w rodzaju poglądowego eksperymentu i zilustrować tekst Piekła za pomocą kilku obrazów z nekropolii Tarkwinii i Caeres" [Vincenz 1997: 253]. Na pewno też oryginalne są jego odwołania do twórczości Adama Mickiewicza i wskazanie na wspólne - ludowe - źródło poezji florentczyka i autora Dziadów [zob. np. Vincenz 1994]. Przytaczając przykłady obrzędowych zachowań praktykowanych w niektórych wsiach Tarkwinii jako przeżytków etruskich, Vincenz wyraża po raz kolejny przekonanie o „nieprawdopodobnie twardym życiu” archaicznego folkloru, który potrafi trwać tysiące lat.

\section{2. „Nerw prawdziwie europejski” w Neapolu}

Podczas pobytu we Włoszech w 1958 roku powstał również List $z$ Neapolu opublikowany rok później w paryskiej „Kulturze”, a skierowany do Czesława Miłosza jako odpowiedź na esej La Combe. Ów „dialog”8 z młodszym przyjacielem, uczniem i późniejszym noblistą przynosi garść podróżniczych refleksji pisarza. Zanurzony jest w pejzażu kulturowym południa Italii, który ma pełnić funkcję ilustracji głównej tezy Listu... Została ona zaczerpnięta z eseju Miłosza i wskazywała, że Vincenz reprezentuje typ emigranta, który „nie został znikąd wygnany” [Vincenz 1959: 22]. Od razu trzeba zasygnalizować tu pewną uwagę - owszem, pisarz utożsamiał się z tym poglądem, jednak nigdy nie opuścił Europy. Alpejska wioska La Combe, w której spędzał co roku kilka miesięcy i gdzie w starym górskim domku przyjmował swoich przyjaciół, odgrywając rolę Sokratesa w stworzonej przez siebie „Akademii”, była dla niego namiastką karpackiego Bystreca. Opisywana w Liście... Italia może być wykładnią tezy o emigrancie „znikąd niewygnanym” właśnie dlatego, że nie tylko jest podobna krajobrazowo do Europy Środkowej, lecz także jest na wskroś europejska, utożsamia europejskiego ducha - o okolicy Neapolu czytamy, że ,jest może jeszcze bardziej dawną Europą niż obecną" [Vincenz 1959: 23]. Aby to zilustrować, autor powołuje się na „szepty”. To jeden z akustycznych, a zarazem symbolicznych sygnałów-znaków, którymi przesycona

8 List nosi podtytuł Dialog z Czesławem Miłoszem. 
jest Vincenzowa Połonina9. Szepty - te najcichsze dźwięki, które może usłyszeć tylko człowiek „świadomy”, mówią coś ważnego, zarówno do mieszkańca huculskiej chaty, jak i do wędrowca w lesie bukowym pod Neapolem. Co prawda, są to nieco inne szepty, ale i tak pozwalają autorowi na uogólnienie: „[...] buki i bukowiny $s q$ ramami Europy" [Vincenz 1959: 23]. Słowa te brzmią niemal jak parafraza stwierdzenia Fernanda Braudela o granicach obszaru śródziemnomorskiego: „Oliwki i drzewa palmowe trzymają wokół niego straż honorową" [Braudel 1994: 15].

Dla Vincenza w jakimś sensie ojczyzną była bowiem cała Europa. Zawsze potrafil wskazać nici wiążące jej odległe regiony, szczególnie jego „ściślejszą ojczyznę” - Huculię - z innymi, bliskimi jej historycznie, krajobrazowo czy kulturowo obszarami. Szepty słyszał zarówno w „Cumae, greckich Kymai, w grotach Sybilli” [Vincenz 1959: 24], które zapewne miał okazję wtedy zwiedzić, jak i w neapolitańskim klasztorze kamedułów oraz w dzielnicy Vomero. Swoje dalsze przeżycia, związane z pogadankami o Homerze, które prowadził z włoskimi uczniami i czytaniem im po włosku fragmentów Połoniny, Vincenz ponownie kwituje odniesieniem do Europy. Opisuje moment, kiedy natknął się na „nerw prawdziwie europejski” [Vincenz 1959: 27], czyli dzieje rodziny matki profesora Dohrna. I tę historię Vincenz kwituje sentencjonalnie: „Mówi się zazwyczaj, że świat jest mały, ale raczej należałoby powiedzieć, że rodzina europejska jest dość wielka i trzyma się mimo wszystko jeszcze co najmniej ostatkami sił" [Vincenz 1959: 28]. Dalej snuje $\mathrm{w}$ podobnym tonie swoje uwagi po spotkaniu z pochodzącym z Warszawy żydowskim proletariuszem, malarzem o nazwisku Rodolfo-Ruwyn, który spotkał w Neapolu swoją przyszłą żonę, polską hrabinę i poetkę Annę Filangeri' ${ }^{10}$. Zakończyl je refleksją o Odyseuszu na wyspie Ischi i Morzu Śródziemnym jako żywiole Odysei. Vincenz nie mógł się czuć wygnańcem w świecie, który był jego „szerszą” ojczyzną. Parafrazuję tu pojęcie „węższej” czy Stanisław Vincenz a muzyka [Żmidziński 2018]. 
„bliższej” ojczyzny, którego pisarz używał, by nie stosować kalki z języka niemieckiego - pojęcia „małej” ojczyzny (Heimat), gdyż uważał, że jest ono nieadekwatne do polskiej tradycji. Jaki był zakres owej „szerszej” ojczyzny? Wydaje się, że odbiciem jej granic geograficznych, określonych obszarem występowania buka, był zasięg promieniowania kultury wyrosłej ze źródła antycznego humanizmu. Aby odnaleźć miejsce, z którego owo źródło wypływa, trzeba zagłębić się w świat Połoniny.

\section{3. „Pępek ziemi jest w Rzymie...”}

„Pępek świata jest w Rzymie, innego nie będzie” [Z: 7] - takie motto otwiera część pierwszą Zwady (drugiego tomu tetralogii) zatytułowaną Źródła. Z następującego później wykładu swoistej dziedziny badań, którą można by nazwać „pępkologią” ", dowiadujemy się, że chodzi o pępek „niegdyś przechowywany w Delfach - co były Rzymem dla helleńskich wątpień i sumień - kamień spadły z nieba” [Z: 9]. Dalej jednak mowa jest również o „bliższym” pępku: „To jajo w łuskach i obłóczkach wielu jaj, ten rdzeń Wierchowiny, ściśnięty wieloma słojami wierchowin i połonin, mędrcy górscy nazwali sobie potajemnie Pępkiem ziemi” [Z: 9]. Owego pępka szuka w podziemnych korytarzach Palenicy jeden z głównych bohaterów całego cyklu: Foka Szumejowy. W istocie „pępek” jest wariantem „centrum świata”, jednak bliższym samemu człowiekowi, nieomal „cielesnym”, mającym istotne związki z ziemią, a więc i ze wszechświatem, który u Platona, a zarazem w Vincenzowym systemie, był dla człowieka czymś opiekuńczym. To właśnie kosmos stanowił dla pisarza, podobnie jak dla Dantego, najszerszą płaszczyzną poszukiwania wspólnoty.

Co jednak wynika z tego, że Rzym był pępkiem świata i dlaczego nim był? Pomocne tu będzie odwołanie się do eseistyki pisarza, w której wielokrotnie nawiązywał do Monarchii Dantego, gdyż idee zawarte w tym traktacie uznawał za godne uwagi nawet $\mathrm{w} \mathrm{Xx}$ wieku ${ }^{12}$. Zwracał uwagę choćby na wyraźne rozdzielenie

11 Użyłem tego pojęcia w moim artykule [Żmidziński 2017].

12 Szerzej omawiam to zagadnienie w artykule Rzeczpospolita Vincenza [Żmidziński 2021]. 
władzy świeckiej i duchowej. Rzym był dla Vincenza ważny jako dawna stolica - symbol takiej właśnie monarchii, utopijnego ustroju politycznego, o którym rozmyślał przez lata. Stąd jego eseje o Gandhim, uwagi o Machiavellim, obszerne passusy poświęcone prawu w Połoninie, szczególnie w Listach z nieba. Aktualnym śladem owego centrum była stolica papiestwa, a na kartach tetralogii padają o nim ciepłe słowa. Gdy na początkowych stronnicach Prawdy starowieku czytamy o górskich ścieżkach - płajach, dowiadujemy się, że z płaju nad Dancerskim „poprzez skały otworzyła się od razu droga do Rzymu” [Ps: 13], tam, gdzie pępek ziemi i „papa-rymski, dziadek najmilszy" [Ps: 13]. Tom ten zamyka wizyta w Rzymie i audiencja u papieża, opisywanego z „naiwną”, niejako ludową sympatią, podobną do tej, z jaką przedstawiany jest w Połoninie cesarz w Wiedniu:

[...] wiele lat temu garstka gazdów huculskich, ze sławnym Foką Szumejowym i rzeźbiarzem Markiem Mehedenym na czele, pojechała pod opieką księdza metropolity lwowskiego do Rzymu. W delegacji do papy-rymskiego, do samego Ojca świętego! Powiadają niektórzy, że tam, a nie gdzie indziej jest pępek ziemi. Przekazują też i dużo o tym gadają, że bardzo dobrze tamtędy jechać na umieranie, bo bliżej nieba. [Ps: 493]

W tym samym tonie narracji, stylizowanym - jak to często bywa w Prawdzie starowieku - na opowieść huculskiego powiastuna, autor wspomina: „[... ] nieźle żyło się w tej rozśpiewanej Italii. Świat pełen krasy, kościoły, kaplice, obrazy, pomniki, mosty, a wino także. Wszystko tak, jak się u nas w bajkach opowiada” [Ps: 495]. Takich cieplych uwag o ziemi włoskiej rozsianych po całej Połoninie jest więcej. Można przypuszczać, że wszystkie są reminiscencją doświadczeń samego autora.

Wspominanego już Fokę Szumejowego poznajemy jako tego, który „bywał w Wenecji” [Ps: 61]. Jeszcze kiedy ukrywał się przed służbą wojskową u niejakiego Fedora, jego brat opowiadał mu o Wenecji należącej wtedy do monarchii austro-węgierskiej. Ponieważ służyli tam Rusini i Huculi, także Foka zapragnął zobaczyć miasto na wodzie. Sam zaciągnął się do służby, a gdy go odesłano 
do Wenecji, traktował ten pobyt raczej rozrywkowo, wykradał się z koszar na zabawy i tańce, śpiewał i chadzał po ulicach. Po kilku miesiącach, za sprawą interwencji jego ojca, odesłano go do domu, ale dzięki tym doświadczeniom „miał o czym opowiadać przez całe życie" [Ps: 79] i zyskał sobie mir w społeczności huculskiej:

Po wielu latach jeszcze, jako stary człowiek opowiadał o tym mieście, że nie wymądrowałby w bajce nic piękniejszego. O tym, jakie tam morze jest oswojone, tak iż każdy pan i gazda łódką pod swój pałac zajeżdża. Opowiadał o tych pałacach, o mostach przedziwnych, powyginanych, o zabawach przepięknych. I o tym, jaki to naród wenecjański dobry, grzeczny, czemny's, i ujmujący jak żaden inny. Jak się lubują w strojach. A w tym wszystkim jakże do naszych chrześcijan, do Huculów podobni. Łagodnie przemawiają, słodko, delikatnie. Nabyłem się z nimi! I muzyki nasłuchałem się, co z tych fal rozświetlonych płynie. [Ps: 79-80]

Tak mówił Foka, jakby relacjonował młodzieńcze wojaże samego Vincenza. Nawet w Barwinkowym wianku przywołane jest „miasto na wodzie", w porównaniu korowodu wozów kierowanych przez żydowskich bałagułów ${ }^{14}$, wiozących gości weselnych do Krzyworówni: „Bałaguły śpiewali, strzelali z biczysk, posuwali się przez wsie podgórskie powoli niczym rozśpiewane łodzie weneckie" [Bw: 99].

Podobne reminiscencje swoich podróży, tym razem z Neapolu, włożył autor w usta Dziedzica, czyli swojego dziadka z Krzyworówni w Listach z nieba. Podczas biesiady w przeszklonej werandzie (zwanej Durijka) mówil do siedzącego obok księdza:

Ten basen szklany coś mi przypomina. W pobliżu Neapolu jest mieścina nad samym morzem. Nic tam zresztą nie ma ciekawego, tylko szklany bazar dla turystów, a raczej dwa bazary w szklanej hali. Na lewo istna fabryka świętych, pomniki dla kaplic i dla grobów. Wybór niezwykły [...] Cały pawilon szklany wypeł- 
niony barwą morza jak tutaj barwą nieba, a na prawo widać przez szkło ciasną zamkniętą uliczkę w kształcie litery V, opadającą ku morzu. Jest tam jakiś cmentarzyk klasztorny. Trumny stojące w szeregu wygiętym jedna obok drugiej, a u czoła ich, u wylotu uliczki, rzeźba Jezusa. Wzlatuje z podstawy i prowadzi ku morzu swój ciąg wybranych w maskach z trumien. Rząd trumien, które wypełniały się w ciągu wieków umarłymi braćmi z klasztoru jest zagięty w takim rozmachu, że zda się wnet spadną z nich maski kamienne i cały szereg wzleci za Nim. [Lzn: 89]

Dodać należy, że Listy z nieba, stanowiące trzeci tom Połoniny, to niemal w całości coś w rodzaju sympozjonu - dysputy na rozliczne tematy prowadzonej przez gości zaproszonych na chrzciny Hafijki, córki Foki Szumejowego. Tytułowe Listy z nieba określają też zasadniczą kanwę tych rozmów.

Jeszcze w ostatnim tomie, Barwinkowym wianku, Neapol opisywany jest, obok Abisynii i Cejlonu, jako miejsce planowanych podróży pana Tytusa [por. Bw: 111]. W tym samym tomie znajdziemy kilka innych akcentów włoskich: wspomniany jest autor Wieczorów florenckich, Julian Klaczko - neofita „ze sfer kabalistycznych Wilna, rzekomo nawrócony pod wpływem Dantego" [Bw: 34] - a także bezimienny genueńczyk, malarz z przełomu XVII i XVIII wieku [zob. Bw: 42-43]. Pojawia się również akcent starożytny:

W każdym kraju jest jakaś oś, jak gdyby odskocznia. Gdy się spogląda z Rzymu ku południowi, oczy natrafiają na światła latarni morskiej miejscowości Gaeta, która nie tylko zasłynęła w niedawnych bojach republikańskich Garibaldiego o Italię, nie tylko dała nazwisko całemu rodowi, lecz skierowała myśl ku Eneaszowi, który właśnie w Gaece po raz pierwszy wylądował. Niemały to dystans dla genezy Rzymu i Italii. [Bw: 35]

Ten passus rozdziału zatytułowanego Mądrość jesienna włączony jest niejako w myśli pani Zuzanny, arystokratki i prababki autora zdążającej na wesele wnuka do Krzyworówni. Wyprzedza jej uwagę o przełęczy Suliguł, otwierającej krainę huculską od strony Węgier. Ta italska wzmianka ma, jako jedna z wielu, uprawomocnić Vin- 
cenzowy sposób czytania krajobrazu, o którym sporo już napisano [zob. np. Kolbuszewski 1996]. Krajobraz w ujęciu pisarza jest bowiem nośnikiem wielu znaczeń, a narosłe wokół niego warstwy historyczne są bodaj najważniejsze. Właśnie odwoływanie się do najdawniejszych warstw historycznych było dla Vincenza rekonstrukcją mitu, który każdy krajobraz tworzył w mentalności jego mieszkańców, choć również omawiany passus jest kolejnym przykładem w ciągu analogii łączących Polskę z Italią.

Jednak najważniejszy włoski akcent Połoniny pisarz umieścił w tomie drugim, Zwadzie. Chodzi o „Italianów” pracujących przy wyrębie w czarnohorskich lasach. Wśród nich był też Kamio, którego pragnął usynowić jeden z głównych bohaterów cyklu, gazda z Ilci Tanasij Urszega. Młody, biedny Włoch zachodził do starca, by go rozweselić. Udawało mu się to, gdyż znał przeróżne sztuki cyrkowe. Foce, który wysłuchał opowieści Tanasija podczas przejazdu na butyn (wyręb), nie dane jednak było poznać Kamia. Kiedy przybył na miejsce, Kamio już nie żył. Jego ciało odnaleziono zasypane śniegiem na dnie wąwozu - zapewne zabiła go spadająca kłoda. W nocy rozpoczął się tradycyjny huculski obrzęd pogrzebowy posiżinie, który jednak nie spotkał się ze zrozumieniem Włochów. Wesołe wspominanie nieboszczyka w noc po jego śmierci nie było przez nich akceptowane i dopiero Foka wytłumaczył im w ich rodzimym języku sens tych zachowań. Jest to jedno z kilku miejsc w Potoninie, w których Vincenz zestawia przedstawicieli dwóch nacji o odmiennej mentalności i szuka między nimi nici porozumienia. I tu, inaczej niż między rębaczami a międzynarodową dyrekcją trustu drzewnego, ta nić została odnaleziona. Stało się tak dzięki wysiłkom Foki oraz miejscowego powiastuna (opowiadacza), Andrja Płytki, który opowiedział o swojej znajomości ze zmarłym, bezdomnym skoczkiem cyrkowym, a szczególnie o tym, jak Kamio wydobył go z zaspy i uratował mu życie. Istota charakteru i sytuacja życiowa młodego Włocha zawiera się w początkowych słowach Andrijka:

Chodzi sam po lesie i nieraz sobie zaśpiewa po italiańsku i zawodzi jakoś: „Kiełba - koza - baciar - liaroza ${ }^{15}$. Powiadam 
do niego: - „Co tobie, bracie Kamio, wciąż ta kobyła i koza w głowie?” A on w śmiech: - „Idź het, Andrijko, to nie kobyła ani koza żadna, a dziewczyna kraśna, kapujesz? Tak, aby ją pocałować." To mu w głowie było! I to wam powiadam, bo wiem: on poszedł w puszczę na te roboty przez to, że był sam, samiutki na całym świecie. Mówił mi to po naszemu, tak jak potrafil: - „Mama nima, tata nima, brat nima, żena nima! Niente, niente, nima! Tak ja na ferowija (to po ichniemu kolej) i aż tu na butyn ..." I to wam jeszcze powiadam: on zginą także od tego, że był sam. Jedno, jedyne słowo uratowałoby go. Jedno słowo zatrzymałoby go tam przy ryzie. [Z: 38$]$

Opowieść Andrijka jest bardziej wymowna, jeśli uświadomimy sobie, że jedną z zasadniczych cech Vincenzowego świata jest wspólnotowość: wszyscy bohaterowie należą do jakiejś wspólnoty lub dążą do tego, by się w niej znaleźć. Prócz Kamia chyba tylko stary rekrut wojskowy Pańcio cierpiał z powodu samotności. Samotność bez wspólnoty to śmierć - sugeruje autor. I jeszcze ustami Tanasija dopełnia żalu po samotnym człowieku, który nie doczekał przyjaznego, ratującego życie słowa: „Oj durny ja, durny. Czemuż od razu nie zatrzymałem go u siebie. Ej, Boże, Boże. A wszystko potrafil zrobić. Kochała go chudoba. Przepadło! Żebym choć na posiżinie był zdążył” [Z: 41].

Trudno powiedzieć, dlaczego w powieści Vincenza Włochem był właśnie ten rębacz, który stał się samotną ofiarą lasu zapowiadającą śmierć kolejnych siedmiu huculskich rębaczy. Czy autor chciał podkreślić w losach tego biednego, zarobkowego emigranta wspólnotę dziejów Polaków i Włochów? Na pewno w ten sposób raz jeszcze wyraził swoją sympatię do bliskiego mu narodu. Prawdopodobnie pierwowzorem także tej postaci była jakaś autentyczna, spotkana przez Vincenza osoba...

\section{Rodzinna Italia - rodzinna Europa}

Zgłębiając pisarski warsztat autora Połoniny, przekonujemy się, że jego pisarstwo miało wiele aspektów, przede wszystkim etnogra- 
ficzny ${ }^{16}$, czy nawet publicystyczny [zob. Madyda 2015] (co widzimy głównie w pierwszym tomie), a także aspekt autobiograficzny, o czym przekonuje konstrukcja postaci Foki Szumejowego ${ }^{17}$ i po części również Dziedzica, Tanasija, pana Tytusa czy Władysława - a więc postaci, które często przemawiają głosem autora lub streszczają jego doświadczenia życiowe. Połonina jest w pewnym sensie również sagą rodzinną. Jednak nie chodzi tu tylko o rodzinę w najwęższym tego słowa znaczeniu, bo o tym przekona się każdy czytelnik tetralogii, kiedy już dotrze do końca eposu i zacznie czytać Epilog - Kronikę stanicy górskiej, czyli dworu dziadka Przybyłowskiego w Krzyworówni. Podano tam, które z powieściowych postaci mają swój autentyczny rodowód: począwszy od dziadka autora - Dziedzica Przybyłowskiego - i jego żony Otylii poprzez innych mieszkańców dworu i członków dalszej rodziny, a skończywszy na Foce Szumejowym, który we dworze bywał, i wielu innych postaciach, znanych pisarzowi z dzieciństwa lub z opowieści zasłyszanych w dziecięcym wieku.

Można powiedzieć, że Vincenz wpisał w swoje opus magnum również dzieje rodu Vincenzów i Przybyłowskich. Przekonuje o tym choćby passus o badaczu z Prowansji, umieszczony w pierwszym tomie tetralogii. Był to „emigrant francuski, skoligacony przez żonę z naszym krajem, pan Charles François Joseph de D. [... ] uczony człowiek, doktor medycyny, chirurgii i botaniki wyruszył z Kosowa w góry" [Ps: 452]. Ta opowieść kończy się niewyjaśnioną śmiercią badacza, który „nigdy już nie opowiedział nic swojemu małemu jedynakowi ani o tej krainie, ani o słodkiej Prowansji” [Ps: 455]. Poza uwagą Jerzego Stempowskiego [2015: 372] - „Botanik francuski sprowadzony przez Józefa II na badanie flory Karpat François-Vincent... (spytać Jędrusia). Syn botanika Franciszek Vincenz ożeniony z Kluczyńską" - nie mamy żadnych dowodów, by utożsamić tę postać z przodkiem samego pisarza ani z jakąkolwiek inną postacią historyczną. Biografka pisarza wersji Stempowskiego nie potwierdza - jest to zapewne element mitologii rodzinnej jednak zamieszcza informację: „Foka to Stanisław Vincenz. St. Mówi, że to widać” (5 lutego 1951) [R 1993, nr 1: 24]. 
Przodek pisarza, Charles-François de Vincens zmuszony, jak głosi tradycja rodzinna, do opuszczenia rodzinnego kraju, z początkiem rewolucji francuskiej, udał się do Wiednia, gdzie poślubił piękną Polkę, córkę generała kościuszkowskiego. [B: 14]

Ważniejsza może jest w tej historii geneza rodu Vincenzów. Jak pisze Ołdakowska-Kuflowa: „[... ] przodkowie tej starej hrabiowskiej rodziny przed osiedleniem się w Prowansji władali Vicenzą, stolicą regionu Vicentin w państwie weneckim, czego ślad zachowuje nazwisko" [B: 14].

Ostatnio weryfikacji podań rodzinnych o pochodzeniu Vincenzów podjął się Bogusław Andrzej Baczyński. Jeśli chodzi o przodków od strony ojca, to byli oni raczej urzędnikami, a nie arystokratami: „Wygląda na to, że Vincenzowie zdążają do Lwowa z Moraw" [Baczyński 2019: 321]. Również Przybyłowscy nie należeli do szlachty i jedynie żeńska linia przodków matki pisarza, rodzina Wassilków, ma korzenie szlacheckie. Swoje wnioski badacz konkluduje:

Wydaje się rzeczą słuszną podsumować niniejszy przyczynek do biografii autora Barwinkowego wianka stwierdzeniem, że do licznych odniesień do najdawniejszej genealogii, zawartych w tej i w innych częściach cyklu Na wysokiej połoninie, trzeba podchodzić z rezerwą, w kategoriach arkadyjskiego mitu - tak jak potraktowana została Huculszczyzna i ludzie ją ożywiający. [Baczyński 2019: 330]

Nie mamy pewności, czy Vincenz dobrze znał autentyczne pochodzenie swoich przodków i ich losy; nie wiemy, na ile świadomie kreował ów rodzinny mit, a na ile rzeczywiście wierzył w swoje arystokratyczne, włoskie pochodzenie. Na pewno jednak kwestie tożsamościowe były dla niego niezwykle ważne.

Dlaczego tutaj poświęcamy tyle miejsca na przedstawienie poniekąd legendarnych dziejów odległych przodków pisarza? Ma to ścisły związek ze sposobem jego myślenia, które rzutowało też na samą twórczość. Vincenz szukał ukrytych związków, czę- 
sto tak głęboko ukrytych, że niemal nieobecnych. Przykładem może być drążenie przez niego etruskich korzeni dzieła Dantego. Podobnie myślał o swojej tożsamości, również tożsamości rodzinnej, a szerzej: o tożsamości bliskich sobie nacji i w końcu Europy. Jego główny powieściowy porte-parole, Foka Szumejowy, choć był postacią autentyczną, miał też znaczące imię. W języku rumuńskim (a pisarz miał też przodków rumuńskich od strony matki) foc znaczy „ognisko”, „światło”, natomiast w języku greckim Foc to mieszkaniec Fokidii, krainy, w której leżały Delfy. To właśnie tam umieszczono w ołtarzu kamienny omfalos - pępek ziemi. Jak wiadomo, przedłużenie tamtego pępka sięga do Rzymu, dawnej stolicy imperium i spadkobiercy greckiej kultury, stolicy papiestwa i współczesnych Włoch. I choć Vincenz kiedyś zwierzył się żonie, że posiada, być może, korzenie greckie ${ }^{18}$, równie dobrze mógł poszukiwać swoich przodków w ojczyźnie Dantego - czyż nie po to w młodości on sam, a za nim Foka, udał się do Wenecji, do odległego, legendarnego gniazda swego rodu? To właśnie tego typu myślenie charakterystyczne jest dla pępkologii.

Barwinkowy wianek to najbardziej „rodzinny” tom Połoniny. Opowiada o weselu rodziców pisarza, na które ze wszystkich stron zjeżdżają się przyjaciele i rodzina młodych. Podczas uroczystości pan Lewandowski wygłasza mowę do Żyda Weisera, a rzymskie pochodzenie Polaków przedstawia w niej jako pewnik: „Bez nas Rzymian i bez was Żydów ten kraj byłby zbyt smutny. Wiadomo bowiem powszechnie, mistrz kronikarz wywodzi nas accuratissime od Rzymian" [Bw: 61]. Oczywiście nie jest to deklaracja tożsamościowa pisarza, niemniej ślad jego myślenia, potwierdzający choćby refleksję zawartą w jednym z esejów o latynizacji pojęć politycznych w naszej części Europy. Z kolei Stanisławów, gdzie mieściła się ekspozytura Akademii Jagiellońskiej i kolegium jezuickie, opisano $\mathrm{w}$ „Epilogu” jako „najdalsz[ą] na południowym-wschodzie stanic[e] europejskiej nauki i oświaty” [Bw: 413]. Dla Vincenza bowiem, choć „Matka wspólna” - „córka Słowa” [Bw: 396], jak ją określił przez Vasylków i Kantakuzenów. Takie mi się to bliskie wydaje i dziwne, że takie podobne do Hucułów" (7 lipca 1965) [R 1999, nr 1-4: 188]. 
pan Władysław, była jedyną Ojczyzną. Huculia była tą „bliższą” ojczyzną, zaś „szerszą” - Europa, utożsamiana z tradycją grecko-rzymską, najpełniej obecną i odczuwaną przez pisarza właśnie na ziemi włoskiej, z którą łączyły go więzi nieomal rodzinne. Dlatego pisarz miał prawo nie czuć się „znikąd wygnany”.

Warto więc zabiegać, by zmienić dotychczasową sytuację, którą niedawno scharakteryzowała tłumaczka tekstów polskich na język włoski, Monika Woźniak: „We Włoszech nie było jeszcze żadnych translacji Vincenza. [... ] kanon tekstów Vincenza warto stworzyć, lecz wydaje mi się to mało realistyczne" [Ucherek 2015: 573]. Czas, by „dalsza” ojczyzna upomniała się w ten sposób o pamięć po swoim „śmiałym i wspólnie czującym” [Vincenz 1983a: 189] duchowym spadkobiercy.

\section{Skróty}

B - Mirosława Ołdakowska-Kuflowa, Stanisław Vincenz: pisarz, humanista, orędownik zbliżenia narodów. Biografia

Bw - Stanisław Vincenz, Na wysokiej połoninie, t. 4: Barwinkowy wianek, epilog

Lzn - Stanisław Vincenz, Na wysokiej połoninie, t. 3: Nowe czasy. Ks. 2, Listy $z$ nieba

Ps - Stanisław Vincenz, Na wysokiej połoninie, t. 1: Prawda starowieku. Obrazy, dumy i gawędy z Wierchowiny Huculskiej

R - Irena Vincenzowa, Rozmowy ze Stanisławem Vincenzem

Z - Stanisław Vincenz, Na wysokiej połoninie, t. 2: Zwada

\section{Bibliografia}

Baczyński Bogusław Andrzej (2019) Galicyjsko-lodomeryjska linia Vincenzów, „Teksty Drugie”, nr 3, s. 317-330, [dostęp: 13 stycznia 2021], https://tinyurl.com/y4y33cxd.

Braudel Fernand (1994), Ziemia, w: Fernand Braudel, Roger Arnaldez [współaut.] i in., Morze Śródziemne. Przestrzeń i historia, ludzie i dziedzictwo, przeł. Maria Boduszyńska-Borowikowa, Barbara Kuchta, Adam Szymanowski, Volumen, Warszawa, s. 11-28.

Burda-Fischer Dorota (2015), Stanisława Vincenza tematy żydowskie, Agencja Wydawnicza a linea, Wrocław. 
Grajewski Wincenty (2003), Grecja Vincenza, w: tegoż, Maszyny dialogowe. Szkice teoretycznoliterackie, Universitas, Kraków, s. 133-142.

Kolbuszewski Jacek (1996), „Pismo światowe” Stanisława Vincenza, w: Z problemów aksjologii literatury i kultury popularnej: prace ofiarowane Józefowi Nowakowskiemu, red. Stanisław Uliasz, Wydawnictwo Wyższej Szkoły Pedagogicznej, Rzeszów, s. 41-54.

Madyda Aleksander (2002), O idealizacji Hucuatów w „Na wysokiej połoninie", w: Stanistaw Vincenz - humanista Xx wieku, red. Mirosława Ołdakowska-Kuflowa, Towarzystwo Naukowe KUL, Lublin, s. 163-170.

Madyda Aleksander (2015), Prawda starowieku Stanisława Vincenza jako utwór publicystyczny, w: Zatrudnienie: literat. Materiaty, studia i szkice o Stanistawie Vincenzie, red. Jan Andrzej Choroszy, Agencja Wydawnicza a linea, Wrocław, s. 283-295.

Marbach John (1976), Rozmowa ze Stanisławem Vincenzem, przeł. Jan Torosiewicz, „Wiadomości” [Londyn], nr 7 (1559), s. 2.

Mrugalski Michał (2008), Aktualność Dantego i Kresy Vincenza. Teologia i styl „Na wysokiej połoninie”, „Prace Filologiczne. Seria Literaturoznawcza", t. 50, nr 1, s. 271-305, [dostęp: 13 stycznia 2021], https://tinyurl.com/y2su69k5.

Ołdakowska-Kuflowa Mirosława (2006), Stanisław Vincenz: pisarz, humanista, orędownik zbliżenia narodów. Biografia, Towarzystwo Naukowe Katolickiego Uniwersytetu Lubelskiego Jana Pawła II, Lublin. (Skrót: B)

Pálfalvi Lajos (2002), Tematy węgierskie w twórczości Stanisława Vincenza, w: Stanisław Vincenz - humanista Xx wieku, red. Mirosława Ołdakowska-Kuflowa, Towarzystwo Naukowe KUL, Lublin, s. 61-69. Snopek Jerzy (1994), Vincenz a Węgry, w: Stanisław Vincenz, Atlantyda. Pisma rozproszone z lat II wojny światowej, red. Jerzy Snopek, Świat Literacki, Warszawa, s. 5-18.

Stempowski Jerzy (2015), Historia rodu Vincenzów, w: Zatrudnienie: literat. Materiaty, studia i szkice o Stanistawie Vincenzie, red. Jan Andrzej Choroszy, Agencja Wydawnicza a linea, Wrocław, s. 371-374. Sucharski Tadeusz (2008), „Duchowe zaplecze” Stanisława Vincenza na „sowiecki zalew”, w: tegoż, Polskie poszukiwania „Innej Rosji”. O nurcie rosyjskim w literaturze Drugiej Emigracji, słowo/obraz terytoria, Gdańsk, s. 159-184.

Ucherek Dorota, oprac. (2015), Dialog o duchu litery, Kolokwium Vincenzowskie, Wroctaw, 15 X 2014, w: Zatrudnienie: literat. Materiały, studia i szkice o Stanistawie Vincenzie, red. Jan Andrzej Choroszy, Agencja Wydawnicza a linea, Wrocław, s. 561-573. 
Vincenz.pl (2021), [dostęp: 13 stycznia 2021], http://www.vincenz.pl.

Vincenz Stanisław (1959), List z Neapolu. Dialog z Czesławem Miłoszem, „Kultura” [Paryż], nr 6 (140), s. 22-29.

Vincenz Stanisław (1980), Arcydzieło a mit ludowy, w: tegoż, Z perspektywy podróży, Znak, Kraków, s. 351-359.

Vincenz Stanisław (1983a), Mała Itaka - dialog nocny, w: tegoż, Po stronie dialogu, t. 1, przedmowa Czesław Miłosz, PIw, Warszawa, s. 178-189.

Vincenz Stanisław (1983b), Polityk niepolityczny, w: tegoż, Po stronie dialogu, t. 2, posłowie Andrzej Vincenz, PIw, Warszawa, s. 101-108.

Vincenz Stanisław (1993), Outopos. Zapiski z lat 1938-1944, autograf odczytał Andrzej Vincenz, tekst $\mathrm{z}$ autografem porównał, opatrzył posłowiem i ilustracjami oraz do druku podał Jan A. Choroszy, Wydawnictwo Dolnośląskie, Wrocław.

Vincenz Stanisław (1994), Dante i Mickiewicz, w: tegoż, Atlantyda. Pisma rozproszone z lat II wojny światowej, wybór, wstęp i oprac. Jerzy Snopek, Świat Literacki, Warszawa, s. 58-68.

Vincenz Stanisław (1997), Czym może być dla nas Dante?, w: Eseje i szkice zebrane, t. 1, wybór i wstęp Andrzej Vincenz, przygotowali do druku Marek Klecel i Andrzej Stanisław Kowalczyk, Wirydarz, Wrocław, s. $197-229$.

Vincenz Stanisław (2002), Na wysokiej połoninie, t. 1: Prawda starowieku. Obrazy, dumy i gawędy z Wierchowiny Huculskiej, Pogranicze, Sejny. (Skrót: Ps)

Vincenz Stanisław (2003), Na wysokiej połoninie, t. 2: Zwada, Pogranicze, Sejny. (Skrót: Z)

Vincenz Stanisław (2004), Na wysokiej połoninie, t. 3: Nowe czasy. Ks. 2, Listy $z$ nieba, Pogranicze, Sejny. (Skrót: Lzn)

Vincenz Stanisław (2005), Na wysokiej połoninie, t. 4: Barwinkowy wianek, epilog, posłowie Andrzej Vincenz, Pogranicze, Sejny. (Skrót: Bw)

Vincenzowa Irena (1993-1999), Rozmowy ze Stanisławem Vincenzem, [zapiski z datą ich sporządzenia (podaną w nawiasie okrągłym) oraz z datą publikacji, numerem czasopisma „Regiony” i zakresem stron]. (Skrót: R)

Woldan Alois (1992), Austria w twórczości Stanisława Vincenza, w: Świat Vincenza. Studia o życiu i twórczości Stanisława Vincenza (1888-1971), red. Jan Andrzej Choroszy, Jacek Kolbuszewski, Leopoldium, Wrocław, s. 127-133.

Zięba Andrzej (2015), O ormiańskich korzeniach Vincenza i ich odbiciu w jego pokuckiej mitologii, w: Zatrudnienie: literat. Materiaty, studia i szkice o Stanistawie Vincenzie, red. Jan Andrzej Choroszy, Agencja Wydawnicza a linea, Wrocław, s. 375-420. 
Żmidziński Jakub (2017), Foki Szumejowego podróże do źródeł. Pępek ziemi w ujęciu Stanistawa Vincenza, „Góry - Literatura - Kultura”, t. 11, s. 179-196, https://doi.org/10.19195/2084-4107.11.12.

Żmidziński Jakub (2018), Wzór nieznany. Stanisław Vincenz a muzyka, Agencja Wydawnicza a linea, Wydział Edukacji Artystycznej i Kuratorstwa Uniwersytetu Artystycznego w Poznaniu, WrocławPoznań.

Żmidziński Jakub (2021), Rzeczpospolita Vincenza, w: Projektowanie niepodległości, red. Wiesław Ratajczak, Marek Osiewicz, Wydawnictwo „Poznańskie Studia Polonistyczne”, Poznań [w druku].

Jakub Żmidziński

“Traveller-dantophile” in Home Italy. Stanisław Vincenz and the Italian Artistic Tradition

The article is the first attempt at a holistic view of Stanisław Vincenz's relationship with Italian culture. Since his youth, Vincenz would visit the Italian Peninsula travelling to Venice and, already as an emigrant after World War II, made a few visits to Naples and Tuscany. These journeys resulted in numerous comments included in his essays on Dante Alighieri, as separate overview $Z$ perspektywy podróży (From a traveller's perspective) and List $z$ Neapolu. Dialog z Czestawem Miłoszem (A letter from Naples. A dialogue with Czestaw Mitosz). Italian journeys, interest in Dante and Italian culture (architecture, painting, folk rituals) brought numerous Italian motifs in the tetralogy Na wysokiej potoninie (On a high mountain pasture). The key element is included in volume II, Zwada (Conflict), which describes a group of loggers cutting down trees in a primeval Carpathian forest. In this part, a young Italian dies and is buried after a Hutsul funeral ritual which is not understood by the foreigners. The analysis of the abovementioned motifs shows how important Italian culture was to Vincenz, also in a very personal sense, given the Vincenz family's distant Venetian roots. One may even claim that for the writer, Italy was almost a family land. Personifying the European spirit, Italy was his "broader" homeland.

Keywords: Stanisław Vincenz; Italy; Naples; Venice; Dante. 
Jakub Żmidziński - pracuje na stanowisku profesora na Wydziale Edukacji Artystycznej i Kuratorstwa Uniwersytetu Artystycznego w Poznaniu. Autor dwóch monografii: Pieniny w literaturze polskiej (2010) i Wzór nieznany. Stanisław Vincenz a muzyka (2018). Zajmuje się m.in. motywami górskimi i muzycznymi w literaturze, tematyką rytuału i korespondencji sztuk, kulturowym wymiarem muzyki. Wydał trzy tomiki poetyckie: domek (2011), Węgliska i inne wzgórza (2012) oraz Ślad (2016). 
